\title{
Analysis of the Use of Electronic Money in Efforts to Support the Less Cash Society
}

\author{
Dwi Wulandari \\ Faculty of Economics, Universitas Negeri Malang, Malang, Indonesia \\ E-mail: wulan501@yahoo.com \\ Thomas Soseco \\ Faculty of Economics, Universitas Negeri Malang, Malang, Indonesia \\ Bagus Shandy Narmaditya \\ Faculty of Economics, Universitas Negeri Malang, Malang, Indonesia
}

Received: Dec. 29, 2015

Accepted: Jan. 6, 2016 Published: Jan. 28, 2016

doi: 10.5296/ifb.v3i1.8802

URL: http://dx.doi.org/10.5296/ifb.v3i1.8802

\begin{abstract}
Technological developments have had an impact on all aspects of life including changes to existing payment systems. Electronic money (E-Money) is a non cash payment instrument in addition to credit cards and debit cards. E-money offers advantages over debit cards and credit cards that give the ease, speed, and efficiency. The issue discussed in this research covers the intensity of the use of e-money, the volume of transactions, preferences, and perceptions about the use of e-money at the Faculty of Economics, State University of Malang. This study used a qualitative approach. The findings showed that only a small portion of the respondents $(17.07 \%)$ has already been used BRIZZI card as a means of payment. Majority of students simply do as much as 3-5 times transaction per month. The volume of transactions in using E-money is still low. Student preference to use BRIZZI is relatively small. Most of the respondents supported less cash society because they believe it will promote economic growth and stability.
\end{abstract}

Keywords: E-money, Less cash society, BRIZZI 


\section{Introduction}

The world's financial system that exists today is the result of the development and evolution a few centuries ago. Technological development has an impact on all aspects of life including changes of the existing payment system. Cash payment instrument by using money has begun to shift to non-cash payment instruments. The development of the use of non-cash payments are not only separated from technological development but also supported the government's efforts towards Less Cash Society. Simply stated Less Cash Society interpreted the use of fewer cash transactions. While Bank Indonesia campaign of the Non-Cash National Movement/Gerakan Nasional Non Tunai (GNNT) on August, 14, 2014. The use of non-payment cash in Indonesian society is still relatively low compared to other countries. Cash transactions in Indonesia covers $99.4 \%$ of total national transactions. This figure is higher compared to other ASEAN countries such as Thailand (97.2\%), Malaysia (92.3\%) or Singapore (55.5\%) (Gerai info BI Edisi 50 Tahun 2014).

Quoting from MasterCard Advisors that released a report of latest global Cashless entitled The Journey that examines five regional states including developed countries and developing countries, non-cash payments in Indonesia now accounts for 31 percent of the total payments made by consumer. This puts Indonesia in the category of countries that are in the early stage (inception) together with other countries, such as Nigeria, Russia, and Colombia.

When viewed from the penetration of credit card and ATM/Debit Card, Indonesia is also still relatively low. Bank Indonesia noted that in 2014 there were 15,124,109 outstanding credit cards in Indonesia. Meanwhile there are 83,765,345 common ATM card that also serves as a debit card. The numbers are still very small compared to the overall Indonesia's population, especially when seen further, that there is a possibility of one person has more than one credit card and/or more than one debit card. During its development, the e-money appears as complementary non-cash payment instruments that have been used there. E-money can be in the form of a prepaid card (e.g., BCA Flazz, Indomaret Card, and BRIZZI) as well as an electronic wallet (such as T-Cash by Telkomsel, Purse of Indosat, and XL Cash from XL). There are many advantages of e-money over credit card and ATM/ debit card is in terms of ease, speed and efficiency.

Transactions using electronic cash unspecified minimum number of transactions that is relatively small. In addition, because no security verification process (either by PIN or signature), the e-money transactions is relatively quickly. The use of e-money in some countries such as Singapore already exists since 1996. In Singapore, the use of e-money marked for services in the field of public transport. Other country that is successfully implement electronics money is Hong Kong. E-money in Hong Kong started in1997, which until now has served $95 \%$ of its citizens. Bank Indonesia noted that since 2008, nominal transactions using e-money continued to increase, from about 76.675 billion Rupiah increased to more than 3.319 trillion rupiah in 2014. When viewed from the average daily transactions, the usage of e-money reaches $\mathrm{Rp} 11.1$ billion. This figure increased when compared to the average daily transaction of e-money in May 2014 which amounted to Rp 8.72 billion and compared on April 2015 which amounted to Rp 9.82 billion. A variety of 
new products from various providers then emerge today, there are 17 companies of e-money providers, both bank or non bank financial institutions introducing e-money services in various areas, such as payments for parking, tolls, commuter rail, to goods and services. E-money is also launched in cooperation with certain institutions, so that the ID Card of an agency can also serve as an e-money.

However, since the launching of the National Movement of Non-Cash/Gerakan Nasional Non Tunai (GNNT) on August 14, 2014, the penetration of e-money is still in city area only. Toll roads and commuter trains exist only in large cities only, while shops that accept payment by e-money is still very limited. Judging from the deployment of a city, Jakarta as the capital of the country is still a concentration for the use of e-money. A total of $91.6 \%$ of total e-money is concentrated in Jakarta. Followed Surabaya as the second biggest city in Indonesia that absorb distribution of e-money with a percentage of only $3.1 \%$. Next is Bandung (2.2\%), Semarang (2.8\%) and Medan (0.3\%). (http://www.marsindonesia.com)

Malang-Indonesia as the second largest city in East Java has an economic potential that cannot be underestimated. Malang is famous of Bentoel cigarette industry. Malang city which is an integral region known as Malang (along with Batu Town and District Malang) is a major tourist destination in East Java. Malang is also place for various schools and universities in Indonesia, which makes the city became one of the references of education in Eastern Indonesia. The high economic activity in Malang will carry on the high rate of turnover. However, the use of e-money in the Malang is still considered low. This is due to lack of community involvement will use e-money. More specifically, needs to be seen usage e-money among the student of the Faculty of Economics in 2014 State University of Malang. Since 2014, student card (KTM) UM has been integrated with e-money BRIZZI. KTM thus can be directly used for shopping in merchants in cooperation with BRI. Therefore, it should be investigated to what extent the use of e-money BRIZZI integrated with student card of Universitas Negeri Malang.

\section{Theoritical Review}

Money as a means of payment is the evolution of barter stage. Case and Fair (2007) defines: "Money is anything that is generally accepted as a medium of exchange". Mishkin (2004) defines money as "anything that is Generally Accepted in payment for goods and services or in the repayment of debts". At the beginning, the money can be in the form of beads, shells, or metal. Until now, money may includes banknotes, coins, checks or transfer form.

Mishkin (2004) describes some of the functions of money, namely: First, money as a medium of exchange. Money as a medium of exchange is fundamental specialization and distribution in producing a product, because with the money that people do not have to swap that goods produced in the market and with the money he earned from the sale of it is spent or bought the goods wants. Second, money as a unit of account. With this function, the value of an item can be measured and in the comparison. Third, money as a store of value. The functions associated with human nature as collectors of wealth. Fourth, money as a tool for future payments. By itself the value of which is determined based on the monetary standard belief, this indicates that the value of the rupiah is not guaranteed by certain heavy metals (gold) but set by government 
through Bank Indonesia. This is because Bank Indonesia is an institution that has the right to print and circulate rupiah as currency.

In its development, moving towards the payment instrument and electronic cards, for example credit cards, ATM/debit, and e-money. E-money is seeded into a means of payment intended for transactions of small value. Various studies have shown the benefits of using e-money as maximum flexibility in payment transactions in small nominal amount. For example, in transport, in cinemas, clubs, and the payment of fines, taxes and court orders. It is very easy to make calculations on the internet when buying traditional and electronic products such as the purchase of computer software, etc. (Miller et al., 2002).

E-money payment process can be done quickly and there is no common problem such as queues. E-money is transferred from the payer to the recipient within seconds. E-money have significant advantages compared with cash, but it has also drawbacks. Central banks in many countries are concerned about the development of e-money, especially on the issuance (emission) e-money that are not controlled and the risk of infringement appearing (Hespeler, 2008).

Woda (2006) shows that e-money has the potential to provide a wide range of positive effects, such as comfort and privacy, the reduction in costs associated, potential new business, as well as the transfer of financial activities among communities on the Internet. However, there are controversial issues that arise concerning the introduction of e-money. Establishment of electronic currency raises a number of issues relating to taxation and allegations of money laundering. Also, the concern about confidentiality and the possibility of leakage of personal data of citizen.

Athanassiou \& Mas-Guix (2008) said e-money has a negative impact on the macro economy such as exchange rate volatility and the lack of guarantees for real money. Lack of collateral real money appeared because of the allegations at a certain point, the amount of virtual money will probably exceed the amount of real money. Problems associated with the use of e-money may also occur due to liquidity problems issuer (issuer) them, as well as the consequences of the obligations imposed by the issuer. Humphrey et al. (1996) expressed concerns about security and consumer protection is a major issue in the use of e-money, such as in case of loss or theft of the e-money. E-money can be easily used by other parties who are not responsible for unauthorized e-money in the form of a Personal Identification Number (PIN) or signature such as credit card and ATM card/debit.

Mishkin (2008) states although the use of e-money will increase in the future, but the community without $100 \%$ cash would not have been possible. E-money provides greater convenience and more efficient than cash payment system, there are several factors that do not support the loss of cash payment system, for example: First, the cost required to build a network of computers, card readers, and the necessary networks to make e-money to be the dominant form of payment would be very expensive. Second, electronic payment instruments to encourage an increased risk of security and privacy considerations. This is indicated by the possibility of transfer of funds from one account to another illegally. In addition, the concern is 
that governments, employers, or e-money providers can access the personal data of customers that disrupts the confidentiality of personal data.

Some of the factors that predispose a person to use or not to use e-money are the risks and perceived safety that can then affect the customer's perception in general banking activities, activities of e-banking, e-payment and online payment (Jebran \& Dipanker, 2012; Ozkan, 2009). Miliani et al. (2013) found that the main factor affecting the behavior of the customer adoption of e-money is the main perceived benefit of customers. While the risks and safety considerations do not diminish or affect consumer intention to adopt e-money.

Davis (1989) defines a person's perceived benefits in line with the degree to which a person believes that the use of certain technologies will improve performance achievement. Taylor $\&$ Todd (1995) define the perception of the benefits through the approximate range of factors such as: job easier, profitable, increase productivity, improve effectiveness, and improve work performance. The benefit of the use of e-money is that it can improve the performance of people who use it. Therefore, the benefit of e-money will affect the attitude of customers in the system. Davis in Jogiyanto (2007, p. 114) explains that the benefits (perceived usefulness) will enhance the decision-making process work if a person feels confident that the information system is useful and he would use it. Conversely, if a person feels or believes that information technology systems that are less useful then he will not use it. These results are supported by Hatta (2010), Rahayu (2012), Moon (2012) which shows that the perception of the benefits are the factors considered by customers using e-money.

In the world of banking, data security and customer privacy is a major factor. Customers are generally reluctant to share personal information with others. Some studies show this, as Howcroft et al. (2002), Polatoglu \& Ekin (2001), Sathye (1999). The reverse is found in the use of e-money. E-money it does not ensure the safety of funds and customer data confidentialit. This is because the e-money does not have security features such as PIN or signature.

E-money is slowly introduced in Indonesia. E-money in Indonesia was introduced in 2007, while in Hong Kong was introduced in 1997 and Singapore in 2000. Because of this, e-money is unknown compared to credit card and ATM/debit card. In fact, e-money is also less well known compared to other banking products such as mobile banking, SMS banking, phone banking, and internet banking.

\section{Methods}

This research is descriptive qualitative. Descriptive is a research method that is trying to describe or depict/describe the phenomenon or the relationship between the phenomenon studied by systematic, factual, and accurate. Descriptive research aims to make researchers can better illustrate the properties known to exist and are relevant to the variables studied. The approach in this study is a qualitative approach to describe respondents toward object based on questionnaires given.

Data collected in this research both use primary and secondary data. Data collection methods used in this research can be divided into two activities: First, the primary survey. This is a survey that conducted to obtain authentic data. To obtain primary data, researchers did multiple 


\section{Macrothink}

data collection techniques which include: (1) observation, is observing something through vision and hearing. (2) questionnaire, data collection through filling a questionnaire conducted on Faculty of Economics' students. Total questionnaire submitted to researchers were 235, which able to represent all of students of Faculty of Economics. (3) interview, a dialogue conducted by researchers to obtain information from sources directly. In this phase, researchers used guided interview to several students who are considered to understand well the use of e-money. Second, the is secondary data survey, which conducted to obtain data from library, internet, journals and articles

\section{Results and Discussion}

The use of BRIZZI by students is still low, as seen in Figure 1.

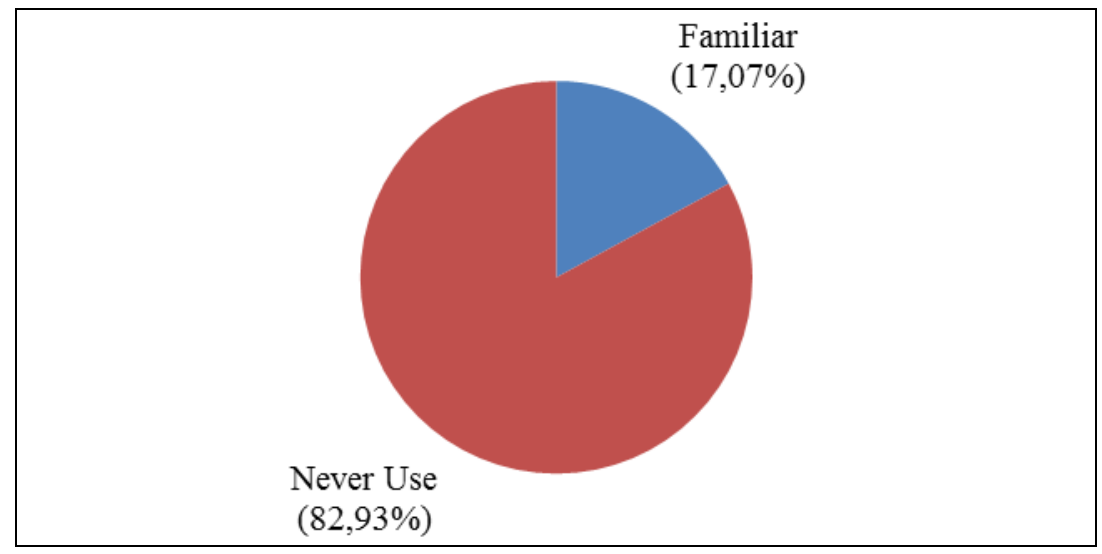

Figure 1. The use of BRIZZI among students of faculty of economics

From Figure 1, only $17.07 \%$ of students of Faculty of Economics are familiar to use BRIZZI. The rest $82.93 \%$ never use BRIZZI card. In addition, knowledge of the use of e-money among the students is still low. Most students still love the cash payment system. Their consideration are fearness of using non cash payment will drive them to be more consumptive. Other consideration is security. Students affraid about their personal data and also money kept in system. In the banking system, generally, customers are reluctant to share personal information with others. Some studies show this, as Howcroft et al. (2002), Polatoglu \& Ekin (2001), Sathye (1999). The reverse is found in the use of e-money. E-money it does not ensure the safety of funds and customer data confidentiality. This is because the e-money does not have security features such as PIN or signature.

Students of the Faculty of Economics, University of Malang partially own the means of payment other than BRIZZI, for example debit cards and credit cards. This is one of the factors why students rarely use KTM BRIZZI for transaction, as seen in Figure 2. Many students also claimed it is hard to use BRIZZI because not enough socialization. BRIZZI which is integrated to campus' student card seemeed campus' obligation to distribute ID card to it's member. 


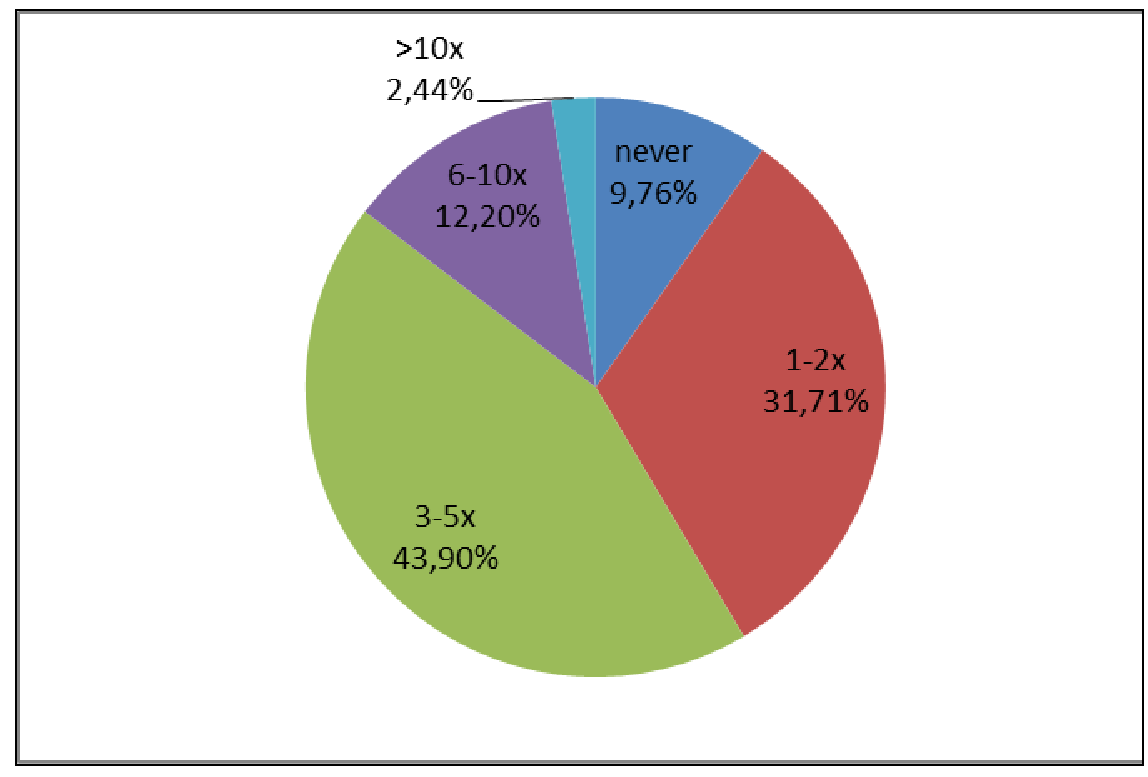

Figure 2. Frequency of use of BRIZZI

Figure 2 shows the use of BRIZZI. About $9 \%$ of students never use that card. Then, more than $30 \%$ of them use BRIZZI 1 to 2 times a month. Most of students (43.90\%) use BRIZZI 3-5 times in a month.

Based on the findings, most students prefer to use cash as payment of various daily necessities. Major students give reason that they only make payments or transactions in small amounts, therefore they do not need e-money or debit/credit cards that have minimum amount to pay. It is contrary to the view of Miliani et al. (2013) who found that the main factor affecting the behavior of the customer adoption of e-money is the main perceived benefit of customers. While the risks and safety considerations do not diminish or affect consumer intention to adopt this electronic.

Most of the students agreed with the National Movement of Non-Cash (GNNT). But most students want the ease of payment systems. Such as ease of operation systems and policies in terms of protection for users of e-money cards. Based on the survey note that the obstacles that make students reluctant to use non-cash payment is due to the policy which is considered difficult in the payment system as the minimum payment that must be made. Though based on field surveys, students often go shopping in small quantities.

Students feel that the benefits of using non-cash instruments is very big because this will increase the efficiency in the transaction as well as ease in daily activities, especially if supported by the security of transactions and individual data and the number of merchants that accept the use of these cards. This is in line Davis (1989) defines a person's perceived benefits in line with the degree to which a person believes that the use of certain technologies will improve performance achievement.

It also supports Taylor \& Todd (1995) which defines the perception of the benefits through the approximate range of factors such as: job easier, profitable, increase productivity, improve 
effectiveness, and improve work performance. The benefits of the use of e-money is that it can improve the performance of people who use it. Therefore, the benefits of e-money will affect the attitude of customers in the system. Similar support is also given to Davis in Jogiyanto (2007: 114) explains that the benefits (perceived usefulness) will enhance the decision-making process work if a person feels confident that the information system is useful and he would use it. Conversely, if a person feels or believes that information technology systems that are less useful then he will not use it. These results also support by Hatta (2010), Rahayu (2012), Moon (2012) which shows that the perception of the benefits are the factors considered by customers using e-money.

\section{Conclusion}

The introduction of e-money that integrated with membership card (e.g., student scrd) does not encourage increase use of e-money instantly. Only $17.07 \%$ of students of Faculty of Economics are familiar to use BRIZZI as medium of payment. Therefore, in order to support the success of the National Movement of Non-Cash (GNNT), it is important to give more intensive socialization about that. One thing to do is to add number of merchants that can receive e-money within the campus, for example cafeterias and a photocopy centres. E-money has actually been able to overcome the problem of permitted minimum amount of transactions with credit cards or debit cards so it is suitable for students who are accustomed to transact in small amount. One important thing is to increase awareness to use e-money. This is important because e-money is easily replaced by cash itself.

\section{References}

Athanassiou P., \& Natalia, M. G. (2008). Electronic Money Institutions Current Trends, Regulatory Issues and Future Prospects. European Central Bank publication.

Conroy, V. (2014). Cashless volumes-The War on cash continues. [Online] Available: http://www.Paymentscardsandmobile.Com/Cashless-Volumes-War-Cash-Continues-2

Davis, F. D. (1989). Perceived Usefulness, Perceived Ease of Use, and User Acceptance of Information Tecnology. MIS Quartely, 13(3), 319-340. http://dx.doi.org/10.2307/249008

Fishbein, M., \& Ajzen, I. (2015). The influence of attitudes on behavior. [Online] Available: http://www.researchgate.net/

Hatta, J. A. (2010). Faktor-faktor yang diopertimbangkan oleh nasabah dalam mengadopsi sistem layanan online banking. Fakultas Ekonomi Universitas Proklamasi 45, Yogyakarta.

Hespeler, F. (2008). Electronic Money and the Monetary Transmission.

Howcroft, B., Hamilton, R., \& Hewer, P. (2002). Consumer attitude and the usage and adoption of home-based banking in the United Kingdom. International Journal of Bank Marketing, 20(3), 111-121. http://dx.doi.org/10.1108/02652320210424205

Humphrey, D., Pulley, L., \& Vesala, J. (1996). Cash, paper, and electronic payments: a cross-country analysis. Journal of Money, Credit, and Banking, 28(4), Part 2: Payment systems research and Public Policy Risk, Efficiency, and Innovation. 
Jebran, K., \& Dipanker, A. (2012). Consumer's Perception on General Banking Activities of Commercial Banks: A Study in the Banking Context of Bangladesh. European Journal of Business and Management, 4(7).

Jogiyanto, H. M. (2007). Sistem Informasi Keperilakuan. Yogyakarta: Andi.

Krzysztof, W. (2006). Money Laundering Techniques with Electronic Payment Systems, Information \& Security. An International Journal, 18, 27-47.

Krzysztof, W. (2006). Money Laundering Techniques with Electronic Payment Systems. Information \& Security. An International Journal, 18, 27-47.

Miller, R., Wolfgang, M., \& Barrie, S. (2002). The Future of Money. OECD PUBLICATIONS.

Mishkin, F. (2004). The Economics of Money, Banking, and Financial Market (7th ed.). Pearson Addison Wesley.

Mishkin, F. (2008). The Economics of Money, Banking, and Financial Market (8th ed.). Pearson Addison Wesley.

Ozkan, S., Gayani, B., \& Ray, H. (2009). Facilitating the adoption of e-payment systems: theoretical constructs and empirical analysis. Journal of Enterprise Information Management, 23(3), 305-325. http://dx.doi.org/10.1108/17410391011036085

Polatoglu, V., \& Ekin, S. (2001). An empirical investigation of the Turkish consumers' acceptance of internet banking services. International Journal of Bank Marketing, 19(4), 156-165. http://dx.doi.org/10.1108/02652320110392527

Purnama, A. C. (2012). Analysis pengaruh daya tarik promosi, persepsi kemudahan penggunaan, perspsi penggunaan, persespsi kemanfaatan dan harga terhadap minat beli e-toll card mandiri (Studi kasus pada pengguna jalan tol di Kota Semarang). Universitas Diponegoro Semarang.

Rahayu, R. (2012). Pengaruh manfaat, kemudahan penggunaan, dan niat terhadap penggunaan aktual kartu flazz bca.. Fakultas Ekonomi Universitas Pendidikan Indonesia Bandung.

Sayte, M. (1999). Adoption of Internet Banking by Australian Consumers: an empirical Investigation. The International Journal of Bank Marketing, 17(70), 324-334.

Sova, K. (2013). Electronic Money Trends in User's Prespective. [Online] Available: https://www.theseus.fi/bitstream/handle/10024/54896/Sova_Kristina.pdf?sequence=1

Taylor, S., \& Todd, P. A. (1995). Understanding Information Technology Usage: A Test of Competing Models. Information Systems Research, 6(2), 144-176. http://dx.doi.org/10.1287/isre.6.2.144

Thomas, H. (2015). Measuring progress toward a cashless society. [Online] Available: http://www.mastercardadvisors.com/_assets/pdf/MasterCardAdvisors-CashlessSociety.pdf 


\section{Macrothink}

International Finance and Banking ISSN 2374-2089 2016, Vol. 3, No. 1

Widya., \& Arnlod. (2015). Transaksi Tunai Masih Mendominasi di Indonesia. [Online] Available:

http://Beritadewata.Com/Ekonomi-Dan-Bisnis/Berita-Ekonomi/Transaksi-Tunai-Masih-Men dominasi-Di-Indonesia.Html

Zumar, D. (2014). E-money baru dikenal 23\% Masyarakat di Indonesia. [Online] Available: http://www.marsindonesia.com/newsletter/e-money-baru-dikenal-23-masyarakat-di-indonesia

Zumar, D. (2013). Master Card Advisors. Cashless Journey Spotlight on Indonesia. [Online] Available:

http://www.mastercardadvisors.com/cashlessjourney/content/MasterCard_Advisors_Cashless Journey_INDS.pdf

\section{Copyright Disclaimer}

Copyright for this article is retained by the author(s), with first publication rights granted to the journal.

This is an open-access article distributed under the terms and conditions of the Creative Commons Attribution license (http://creativecommons.org/licenses/by/3.0/). 